\title{
Genetic basis of rotator cuff injury: a systematic review
}

\author{
Umile Giuseppe Longo ${ }^{1 *} \mathbb{D}$, Vincenzo Candela ${ }^{1}$, Alessandra Berton ${ }^{1}$, Giuseppe Salvatore ${ }^{1}$, Andrea Guarnieri ${ }^{1}$, \\ Joseph DeAngelis², Ara Nazarian² and Vincenzo Denaro'
}

\begin{abstract}
Background: Rotator cuff disease is a widespread musculoskeletal pathology and a major cause of shoulder pain. Studies on familial predisposition suggest that genetic plays a role in the pathogenesis of rotator cuff disease. Several genes are responsible for rotator cuff disease. The aim of this study was to perform a systematic review on genetic association between rotator cuff disease and genes variations.

Methods: A systematic review of the literature was performed, in accordance with the PRISMA guidelines. PubMed, Medline, CINAHL, Cochrane, Embase and Google Scholar databases were searched comprehensively using the keywords: "Rotator cuff", "Gene", "Genetic", "Predisposition", "Single-nucleotide polymorphism" and "Genome-wide association".

Results: 8 studies investigating genes variations associated with rotator cuff tears were included in this review. 6 studies were case-control studies on candidate genes and 2 studies were GWASs. A significant association between SNPs and rotator cuff disease was found for DEFB1, FGFR1, FGFR3, ESRRB, FGF10, MMP-1, TNC, FCRL3, SASH1, SAP30BP, rs71404070 located next to cadherin8. Contradictory results were reported for MMP-3.

Conclusion: Further investigations are warranted to identify complete genetic profiles of rotator cuff disease and to clarify the complex interaction between genes, encoded proteins and environment. This may lead to individualized strategies for prevention and treatment of rotator cuff disease.
\end{abstract}

Level of evidence: Level IV, Systematic Review.

Keywords: Rotator cuff, Gene, Genetic, Shoulder, Predisposition

\section{Background}

Rotator cuff disease is a widespread musculoskeletal pathology and a major cause of shoulder pain [1]. This disabling condition has high prevalence, affecting $30-50 \%$ of the population older than 50 years of age [2]. Rotator cuff disease is a common health concern among working populations. The impact of this condition on earnings, missed workdays, and disability payments is relevant [2].

The etiology of rotator cuff disease is multifactorial [2-7] and its pathogenesis is not completely understood. In addition to aging, several factors can contribute to its etiopathogenesis, such as overuse, mechanical impingement, and smoking $[3,5,8]$. Studies on familial predisposition

\footnotetext{
* Correspondence: g.longo@unicampus.it

1 Department of Orthopaedic and Trauma Surgery, Campus Bio-Medico

University, Via Alvaro del Portillo, 200, Trigoria, 00128 Rome, Italy

Full list of author information is available at the end of the article
}

suggest that genetic plays a role in the pathogenesis of rotator cuff disease. Family members of patients with rotator cuff tears have a significantly higher risk of rotator cuff tears than general population $[9,10]$. Tashjian et al. determined an increased risk of tears in family members of patients with rotator cuff tears that extends out and beyond thirdcousin relationships [11]. Genetic predisposition may play a role also in clinical presentation and progression of rotator cuff tears. Genetically susceptible patients experience symptoms more often [12-15], in fact the relative risk of having a painful tear is 1.44 for siblings of a symptomatic patient [16]. These inheritable characteristics may affect any point of the sensorineural pathway. Moreover, the progression of a tear over a five-year period, is greater in siblings than in controls (tear size increased in $16.1 \%$ of siblings, compared with $1.5 \%$ of control group) [16].

(c) The Author(s). 2019 Open Access This article is distributed under the terms of the Creative Commons Attribution 4.0 International License (http://creativecommons.org/licenses/by/4.0/), which permits unrestricted use, distribution, and reproduction in any medium, provided you give appropriate credit to the original author(s) and the source, provide a link to the Creative Commons license, and indicate if changes were made. The Creative Commons Public Domain Dedication waiver (http://creativecommons.org/publicdomain/zero/1.0/) applies to the data made available in this article, unless otherwise stated. 
Several genes are responsible for rotator cuff disease. Genetic susceptibility may affect the ultrastructure of the tendon. Achilles tendinopathy has been associated with polymorphisms of tenascin $\mathrm{C}$ and collagen type $\mathrm{Va}$ [17]. Similar mechanisms could play a role in the pathogenesis of rotator cuff disease. The genetic basis of this condition may also result from aberrations in the normal cell regulation of apoptosis and tissue regeneration.

The aim of this study was to perform a systematic review on genetic association between rotator cuff disease and candidate genes.

\section{Methods}

A systematic review of the literature was performed in accordance with the Preferred Reporting Items for Systematic Reviews and Meta-Analyses (PRISMA) guidelines with a PRISMA checklist and algorithm.

A comprehensive search of MEDLINE, PubMed, Cochrane, EMBASE, CINAHL, and Google Scholar databases using various combinations of the keywords: "Rotator cuff", "Gene", "Genetic", "Predisposition", "Genome-wide association", "Single-nucleotide polymorphism" was performed. Three independent reviewers (U.G.L., V.C., and A.B.) conducted the search separately. All scientific journals were considered, and all relevant studies were analysed.

In order to qualify, an article must have been published in a peer-reviewed journal All articles were initially screened for relevance. The three investigators separately reviewed each abstract and completed a close reading of all articles to minimize selection bias and error. According to the Oxford Centre of EvidenceBased Medicine, only Level I to Level IV articles in English were included in our study.

We included articles that described genetic variations (single-nucleotide polymorphism, SNP) associated with rotator cuff disease. Both case-control studies focused on candidate genes and Genome-wide association studies (GWASs) were included. Studies should clearly describe the criteria used for the diagnosis of rotator cuff disease, genes and SNPs investigated. Missing data relevant to these parameters warranted exclusion from this systematic review. We did not included studies about familial predisposition, genetic variants and gene expression patterns associated with rotator cuff disease and/or healing. Literature reviews, case reports, animal and cadaveric studies, technical notes, letters to the editor, and instructional courses were excluded.

Finally, in order to avoid bias, the selected articles and their references, and the articles excluded from the study were reviewed, evaluated, and discussed by all the authors. All investigators independently extracted the type of study, number of cases and controls, diagnostic criteria of rotator cuff disease, investigated genes, mean age of cases and controls.

\section{Quality assessment}

We used the Coleman Methodology Score to assess the quality of the selected studies (CMS) [18], in which ten criteria are used to render a score ranging from 0 to 100 points (a score of 100 indicating a study that largely avoids chance, various biases, and confounding factors). The final score is defined as excellent (85 to 100 points), good (70 to 84 points), fair (50 to 69 points), and poor ( $<50$ points).

The subsections of the CMS are based on the subsections of the CONSORT statement outlined for randomized controlled trials, which have been modified to allow for other trial designs. Coleman criteria were subjected to modification in order to make them reproducible for this systematic review. Each study was scored by the three reviewers (U.G.L., V.C. and A.B) independently and in triplicate.

\section{Results}

The literature search and the cross-referencing process resulted in 251 articles. 213 studies were assessed for relevance by title and abstract. 38 duplicates were removed and 200 were excluded because they did not meet inclusion criteria. After reading the remaining fulltext articles, we rejected 3 studies about familial predisposition and 2 studies about genetic expression. Finally, 8 articles were included in the present review [19-26]. The flow-chart of literature search is shown in Fig. 1. Features of the studies are shown in Table 1.

\section{Genetic variations}

8 studies investigating genes variations associated with rotator cuff tears were included in this review. 6 studies were focused on candidate genes [19-24] and 2 studies were GWASs [25, 26].

The following candidate genes were investigated: DEFB1, DENND2C, ESRRB, FGF3, FGF10, FGFR1, MMP-1, MMP-2, MMP-3, MMP-9, MMP-13, Col5A1, TNC, FOXP3, FCRL3. A significant association between SNPs and rotator cuff disease was found for DEFB1, FGFR1, FGFR3, ESRRB, FGF10, MMP-1, TNC, FCRL3. Contradictory results were reported for $M M P-3$ [21, 22].

The two GWASs identified the following locus associated with rotator cuff tears: SASH1- rs12527089, SAP30BP - rs820218, rs71404070 located next to cadherin8 $[25,26]$.

\section{Quality assessment}

The mean CMS score was 71 points (range from 71 to 84 ), indicating that the methodological quality of the included studies was good. There was no statistically significant difference among the CMS values of the examiners. 


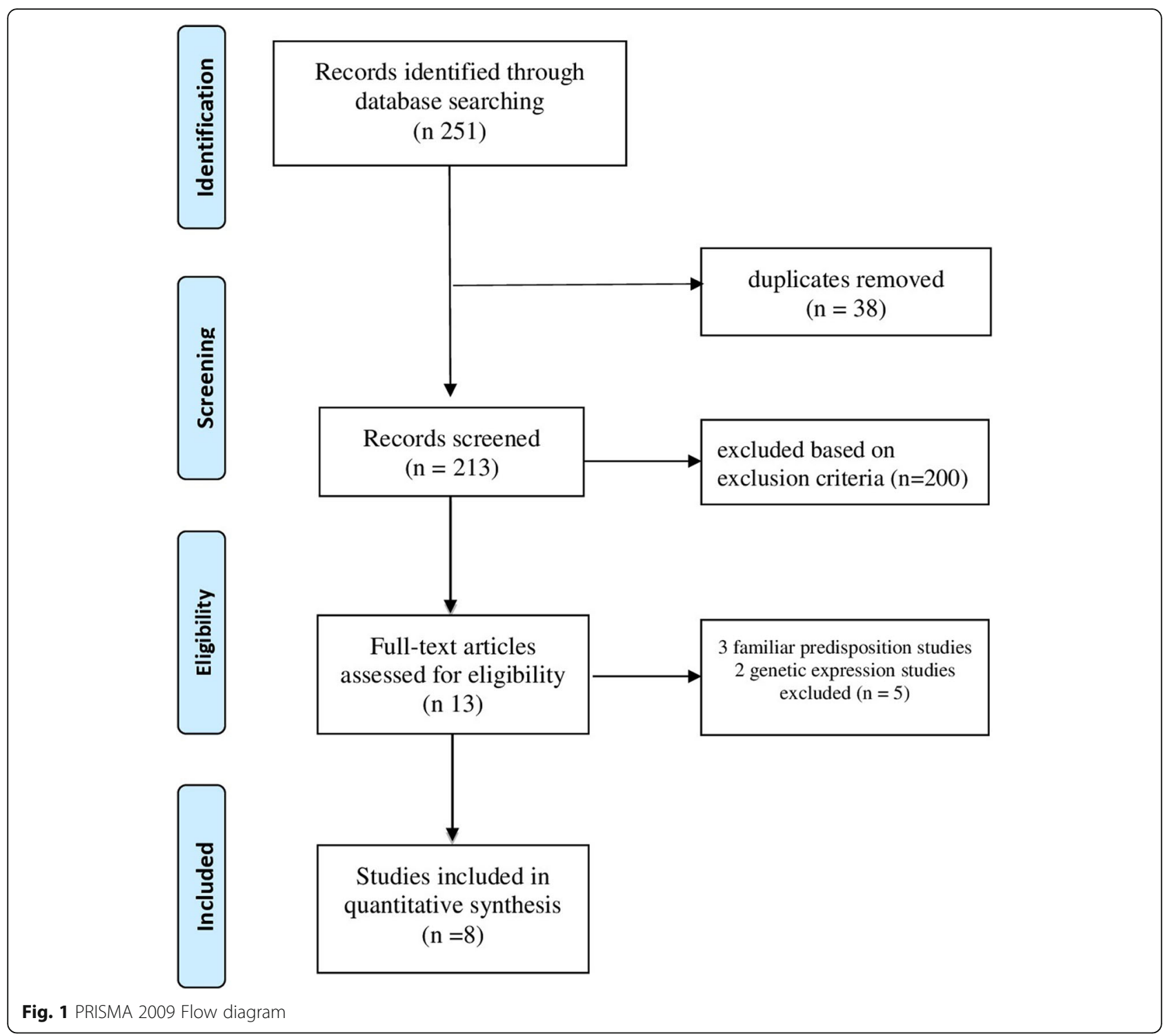

\section{Discussion}

This systematic review outlines the current knowledge in the field of genetics in rotator cuff disease. Preliminary evidences of genetic and familiar predisposition to rotator cuff tears provided the basis for further studies that better highlight the importance of the genetic component in the pathogenesis of rotator cuff disease. In 2017, Dabija et al. [29] reviewed the literature on this topic describing the results of 4 studies investigating familiar predisposition and 3 studies investigating genes associated with rotator cuff tears. Up to day, we found other 5 studies focused on genetic variations associated with rotator cuff diseases. Even if the pathogenesis of rotator cuff disease is still largely unknown, recent studies on candidate genes and GWASs draw attention to SNPs associated with rotator cuff disease [27, 28, 30].
Several genes variations have been associated with rotator cuff tears. Interactions between genes, encoded proteins and environment play a complex role in the development of rotator cuff disease [35].

Motta et al. assessed 23 SNPs in 6 candidate genes (DEFB1, DENND2C, ESRRB, FGF3, FGF10, and FGFR1) in 203 cases and 207 controls [20]. The products of these genes are reported to have a role in tendon repair and degenerative processes. Rotator cuff disease was associated with certain haplotypes in DEFB1, FGFR1, FGFR3, and ESRRB. After adjustment by ethnic group and sex another association in FGF10 was revealed.

The association of variants in ESRRB and rotator cuff disease was further demonstrated by Teerlink et al. [19]. They identified high-risk haplotypes in the ESRRB gene comparing genotypes of 175 patients with rotator cuff tears with 2595 genetically-matched Caucasian controls. 
Longo et al. BMC Medical Genetics

(2019) 20:149

Page 4 of 6

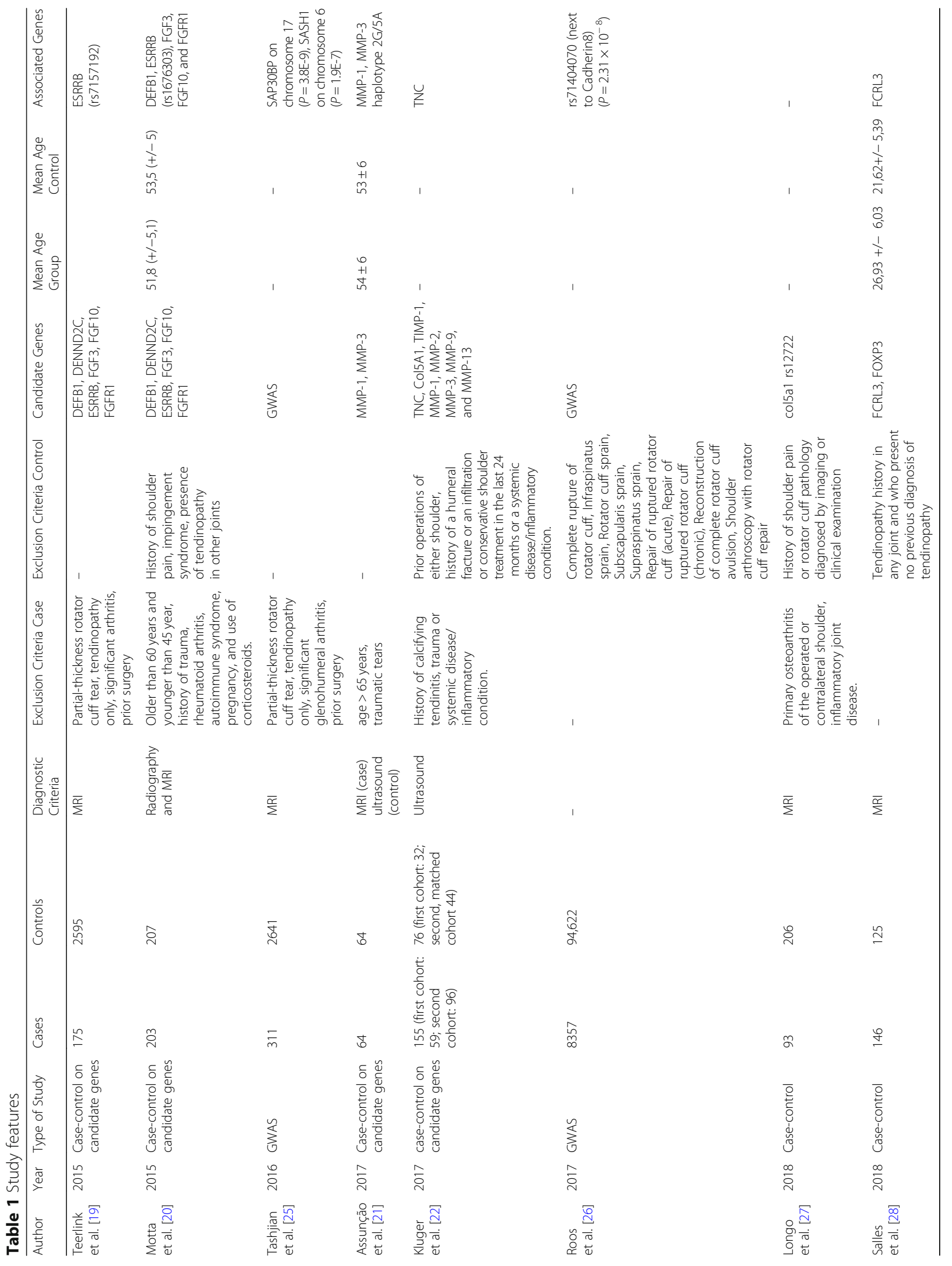


$E S R R B$ is a protein-encoding gene classified as an orphan nuclear receptor, since its exact ligand is not known. It is involved in hearing loss [31], stem cell pluripotency [32], and cellular remodeling of energy consumption under conditions of hypoxia [33]. ESRRB induces hypoxiainducible factor (HIF) transcription, and their interaction may be involved in tenocyte apoptosis [34].

Several studies selected candidate genes on the basis of pre-existing association analyses for Achilles tendon ruptures (TNC, Col5A1, and MMP-3) [35-37], tendinopathies of the elbow (Col5A1) [38], ruptures of the posterior tibial tendon (MMP-1) [39] and matrix metalloproteinase genes $M M P-1, \quad M M P-2, \quad M M P-3, \quad M M P-9, \quad M M P-13$, TIMP-1 that are specifically expressed in torn rotator cuff.

Kluger et al. found no differences in genotype and allele frequencies for SNPs in $M M P-1, M M P-2, M M P-3$, $M M P-9, M M P-13$, and Col5A1 genes while six SNPs in Tenascin-C (TNC) were associated with degenerative rotator cuff tears [22]. Unlike their study, Assunção et al. [21] found a significant association between genetic polymorphism of $M M P-3$ and rotator cuff tearing that may be explained by the smaller number of individuals evaluated, nonpairing between cases and controls for age, and known risk factors such as high blood pressure, and racial and genetic characteristics of the population. Moreover, Assunção et al. studied a different polymorphism in MMP-1 (rs1799750) that was significantly associated with rotator cuff tearing.

In accordance with to Kluger et al. [22], no significant difference in allele and genotype frequencies of col5a1 was observed in the study by Longo et al. [23].

As demonstrated in in-vivo studies, the immune cells play a key role in the pathophysiology of rotator cuff tears. Salles et al. found an increased risk of tendinopathy associated with $\mathrm{Fc}$ receptor-like 3 polymorphism $(F C R L 3-169 T>C)$ [24]. FCRL3 is a glycoprotein of the immunoglobulin receptor superfamily, expressed in Treg cells that may play a role as a negative regulator of Treg function [40-42].

GWASs are a powerful tool to pinpoint genes that may contribute to the risk of developing rotator cuff disease. The GWAS by Tashjian et al. identified two significant SNPs associated with rotator cuff tears: SASH1 (rs12527089) and SAP3OBP (rs820218) [25]. Those genes are associated with the cellular process of apoptosis. SASH1 is a tumor suppressor gene that is ubiquitous expressed and, therefore, may be a potential candidate for dysregulation in musculoskeletal tissue. SAP30BP is a ubiquitously present transcriptional regulator protein on chromosome 17. It may act as a transcriptional corepressor of a gene related to cell survival [43].

In another GWAS, Ross et al. found a SNP located next to cadherin8 significantly associated with rotator cuff injury. It encodes a protein involved in cell adhesion [26].

\section{Conclusion}

Studies on candidate genes and GWASs identified several genes variation associated with rotator cuff tears, such as DEFB1, FGFR1, FGFR3, ESRRB, FGF10, MMP-1, TNC, FCRL3, SASH1, SAP3OBP, rs71404070 located next to cadherin8.

Further investigations are warranted to identify complete genetic profile of rotator cuff disease and to clarify the complex interaction between genes, encoded proteins and environment. This may lead to individualized strategies for prevention and treatment of rotator cuff disease.

\section{Abbreviations \\ CINAHL: Cumulative Index to Nursing and Allied Health Literature; CMS: Coleman Methodology Score; Col5A1: Collagen type V alpha 1 chain; DEFB1: b-defensin protein; DENND2C: DENN Domain Containing 2C; ESRRB: Estrogen-related receptor-b; FCRL3: FC-receptor-like 3; FGF: Fibroblast growth factors; FGFR: Fibroblast growth factors receptor; FOXP3: Forkhead box P3; GWASs: Genome-wide association studies; HIF: Hypoxia-inducible factor; MMP: Matrix metalloproteinases; PRISMA: Preferred Reporting Items for Systematic Reviews and Meta-Analyses; SAP30BP: SAP30-binding protein; SNP: Single-nucleotide polymorphism; TNC: Tenascin-C}

\section{Acknowledgements}

Not applicable.

\section{Authors' contributions}

All authors have read and approved the manuscript. UGL: manuscript preparation, study design, database interpretation and manuscript revision. VC and $A B$ : manuscript preparation, database interpretation and statistical analysis. AG, GS and AN: manuscript preparation, figures and tables preparation, study design. JDA: Manuscript preparation and database interpretation. VD: Study design, manuscript revision.

\section{Funding}

Not applicable.

\section{Availability of data and materials}

The dataset supporting the conclusions of this article is included within the article.

Ethics approval and consent to participate

Not applicable.

\section{Consent for publication}

Not applicable.

\section{Competing interests}

UGL is a member of the Editorial Board of BMC Musculoskeletal Disorders. The remaining authors declare that they have no conflict of interest.

\section{Author details}

${ }^{1}$ Department of Orthopaedic and Trauma Surgery, Campus Bio-Medico University, Via Alvaro del Portillo, 200, Trigoria, 00128 Rome, Italy. ${ }^{2}$ Carl J. Shapiro Department of Orthopaedic Surgery and Center for Advanced Orthopaedic Studies, Beth Israel Deaconess Medical Center and Harvard Medical School, Boston, MA, USA.

Received: 10 February 2019 Accepted: 26 August 2019

Published online: 02 September 2019

\section{References}

1. Goodier HC, Carr AJ, Snelling SJ, Roche L, Wheway K, Watkins B, Dakin SG. Comparison of transforming growth factor beta expression in healthy and diseased human tendon. Arthritis Res Ther. 2016;18:48.

2. Longo UG, Salvatore G, Rizzello G, Berton A, Ciuffreda M, Candela V, Denaro $\mathrm{V}$. The burden of rotator cuff surgery in Italy: a nationwide registry study. Arch Orthop Trauma Surg. 2017;137(2):217-24. 
3. Longo UG, Berton A, Papapietro N, Maffulli N, Denaro V. Epidemiology, genetics and biological factors of rotator cuff tears. Med Sport Sci. 2012;57:1-9.

4. Del Buono A, Oliva F, Longo UG, Rodeo SA, Orchard J, Denaro V, Maffulli N. Metalloproteases and rotator cuff disease. J Shoulder Elb Surg. 2012;21(2):200-8.

5. Longo UG, Petrillo S, Rizzello G, Candela V, Denaro V. Deltoid muscle tropism does not influence the outcome of arthroscopic rotator cuff repair. Musculoskelet Surg. 2016;100(3):193-8.

6. Longo UG, Forriol F, Campi S, Maffulli N, Denaro V. Animal models for translational research on shoulder pathologies: from bench to bedside. Sports Med Arthrosc Rev. 2011;19(3):184-93.

7. Longo UG, Franceschi F, Ruzzini L, Rabitti C, Morini S, Maffulli N, Forriol F, Denaro V. Light microscopic histology of supraspinatus tendon ruptures. Knee Surg Sports Traumatol Arthrosc. 2007;15(11):1390-4.

8. Linaker $\mathrm{CH}$, Walker-Bone K. Shoulder disorders and occupation. Best Pract Res Clin Rheumatol. 2015;29(3):405-23.

9. Tashjian RZ, Hollins AM, Kim HM, Teefey SA, Middleton WD, Steger-May K Galatz LM, Yamaguchi K. Factors affecting healing rates after arthroscopic double-row rotator cuff repair. Am J Sports Med. 2010;38(12):2435-42.

10. Yamaguchi K, Ditsios K, Middleton WD, Hildebolt CF, Galatz LM, Teefey SA. The demographic and morphological features of rotator cuff disease. A comparison of asymptomatic and symptomatic shoulders. J Bone Joint Surg Am. 2006:88(8):1699-704.

11. Tashjian RZ, Farnham JM, Albright FS, Teerlink CC, Cannon-Albright LA. Evidence for an inherited predisposition contributing to the risk for rotator cuff disease. J Bone Joint Surg Am. 2009;91(5):1136-42.

12. Harvie P, Ostlere SJ, Teh J, McNally EG, Clipsham K, Burston BJ, Pollard TC, Carr AJ. Genetic influences in the aetiology of tears of the rotator cuff. Sibling risk of a full-thickness tear. J Bone Joint Surg. 2004;86(5):696-700

13. Roberti M, Mustich A, Gadaleta MN, Cantatore P. Identification of two homologous mitochondrial DNA sequences, which bind strongly and specifically to a mitochondrial protein of Paracentrotus lividus. Nucleic Acids Res. 1991;19(22):6249-54.

14. Foulkes T, Wood JN. Pain genes. PLoS Genet. 2008;4(7):e1000086.

15. Buskila D. Genetics of chronic pain states. Best Pract Res Clin Rheumatol. 2007;21(3):535-47.

16. Gwilym SE, Watkins B, Cooper CD, Harvie P, Auplish S, Pollard TC, Rees JL, Carr AJ. Genetic influences in the progression of tears of the rotator cuff. Bone Joint Surg. 2009;91(7):915-7.

17. Longo UG, Ronga M, Maffulli N. Acute ruptures of the achilles tendon. Sports Med Arthrosc Rev. 2009;17(2):127-38.

18. Altman DG, Schulz KF, Moher D, Egger M, Davidoff F, Elbourne D, Gotzsche PC, Lang T, Consort G. The revised CONSORT statement for reporting randomized trials: explanation and elaboration. Ann Intern Med. 2001;134(8): 663-94.

19. Teerlink CC, Cannon-Albright LA, Tashjian RZ. Significant association of fullthickness rotator cuff tears and estrogen-related receptor-beta (ESRRB). J Shoulder Elbow Surg/ American Shoulder and Elbow Surgeons [et al]. 2015; 24(2):e31-5.

20. Motta Gda R, Amaral MV, Rezende E, Pitta R, Vieira TC, Duarte ME, Vieira AR, Casado PL. Evidence of genetic variations associated with rotator cuff disease. J Shoulder Elbow Surg. 2014;23(2):227-35.

21. Assuncao JH, Godoy-Santos AL, Dos Santos M, Malavolta EA, Gracitelli MEC, Ferreira Neto AA. Matrix metalloproteases 1 and 3 promoter gene polymorphism is associated with rotator cuff tear. Clin Orthop Relat Res. 2017;475(7):1904-10.

22. Kluger R, Burgstaller J, Vogl C, Brem G, Skultety M, Mueller S. Candidate gene approach identifies six SNPs in tenascin-C (TNC) associated with degenerative rotator cuff tears. J Orthop Res. 2017;35(4):894-901.

23. Longo UG, Margiotti K, Petrillo S, Rizzello G, Fusilli C, Maffulli N, De Luca A, Denaro V. Genetics of rotator cuff tears: no association of col5a1 gene in a case-control study. BMC Med Genet. 2018;19(1):217.

24. Salles JI, Lopes LR, Duarte MEL, Morrissey D, Martins MB, Machado DE, Guimaraes JAM, Perini JA. Fc receptor-like $3(-169 T>C)$ polymorphism increases the risk of tendinopathy in volleyball athletes: a case control study. BMC Med Genet. 2018;19(1):119.

25. Tashjian RZ, Granger EK, Farnham JM, Cannon-Albright LA, Teerlink CC. Genome-wide association study for rotator cuff tears identifies two significant single-nucleotide polymorphisms. J Shoulder Elbow Surg/ American Shoulder and Elbow Surgeons [et al]. 2016;25(2):174-9.
26. Roos TR, Roos AK, Avins AL, Ahmed MA, Kleimeyer JP, Fredericson M, loannidis JPA, Dragoo JL, Kim SK. Genome-wide association study identifies a locus associated with rotator cuff injury. PLoS One. 2017;12(12):e0189317.

27. Longo UG, Berton A, Khan WS, Maffulli N, Denaro V. Histopathology of rotator cuff tears. Sports Med Arthrosc Rev. 2011;19(3):227-36.

28. Denaro V, Ruzzini L, Longo UG, Franceschi F, De Paola B, Cittadini A, Maffulli $\mathrm{N}$, Sgambato A. Effect of dihydrotestosterone on cultured human tenocytes from intact supraspinatus tendon. Knee Surg Sports Traumatol Arthrosc. 2010;18(7):971-6.

29. Dabija Dl, Gao C, Edwards TL, Kuhn JE, Jain NB. Genetic and familial predisposition to rotator cuff disease: a systematic review. J Shoulder Elbow Surg/ American Shoulder and Elbow Surgeons [et al]. 2017;26(6):1103-12.

30. Denaro V, Ruzzini L, Barnaba SA, Longo UG, Campi S, Maffulli N, Sgambato A. Effect of pulsed electromagnetic fields on human tenocyte cultures from supraspinatus and quadriceps tendons. Am J Phys Med Rehabil. 2011;90(2): 119-27.

31. Ben Said M, Ayedi L, Mnejja M, Hakim B, Khalfallah A, Charfeddine I, Khifagi C, Turki K, Ayadi H, Benzina Z, et al. A novel missense mutation in the ESRRB gene causes DFNB35 hearing loss in a Tunisian family. Eur J Med Genet. 2011;54(6):e535-41.

32. van der Laan S, Tsanov N, Crozet C, Maiorano D. High Dub3 expression in mouse ESCs couples the G1/S checkpoint to pluripotency. Mol Cell. 2013; 52(3):366-79.

33. Lundgreen $\mathrm{K}$, Lian $\mathrm{O}$, Scott A, Engebretsen L. Increased levels of apoptosis and p53 in partial-thickness supraspinatus tendon tears. Knee Surg Sports Traumatol Arthrosc. 2013:21(7):1636-41.

34. Millar NL, Reilly JH, Kerr SC, Campbell AL, Little KJ, Leach WJ, Rooney BP, Murrell GA, McInnes IB. Hypoxia: a critical regulator of early human tendinopathy. Ann Rheum Dis. 2012;71(2):302-10.

35. Mokone GG, Gajjar M, September AV, Schwellnus MP, Greenberg J, Noakes TD, Collins M. The guanine-thymine dinucleotide repeat polymorphism within the tenascin- $C$ gene is associated with achilles tendon injuries. Am J Sports Med. 2005;33(7):1016-21.

36. Saunders CJ, van der Merwe L, Posthumus M, Cook J, Handley CJ, Collins M, September AV. Investigation of variants within the COL27A1 and TNC genes and Achilles tendinopathy in two populations. J Orthop Res. 2013;31(4):632-7.

37. September AV, Cook J, Handley CJ, van der Merwe L, Schwellnus MP, Collins M. Variants within the COL5A1 gene are associated with Achilles tendinopathy in two populations. Br J Sports Med. 2009;43(5):357-65.

38. Altinisik J, Meric G, Erduran M, Ates O, Ulusal AE, Akseki D. The BstUI and Dpnll variants of the COL5A1 gene are associated with tennis elbow. Am J Sports Med. 2015:43(7):1784-9.

39. Godoy-Santos A, Cunha MV, Ortiz RT, Fernandes TD, Mattar R Jr, dos Santos MC. MMP-1 promoter polymorphism is associated with primary tendinopathy of the posterior tibial tendon. J Orthop Res. 2013;31(7):1103-7.

40. Swainson LA, Mold JE, Bajpai UD, McCune JM. Expression of the autoimmune susceptibility gene FCRL3 on human regulatory T cells is associated with dysfunction and high levels of programmed cell death-1. J Immunol. 2010;184(7):3639-47.

41. Chistiakov DA, Chistiakov AP. Is FCRL3 a new general autoimmunity gene? Hum Immunol. 2007;68(5):375-83.

42. Nagata $\mathrm{S}$, Ise T, Pastan I. Fc receptor-like 3 protein expressed on IL-2 nonresponsive subset of human regulatory T cells. J Immunol. 2009;182(12): 7518-26.

43. Meng Q, Zheng M, Liu H, Song C, Zhang W, Yan J, Qin L, Liu X. SASH1 regulates proliferation, apoptosis, and invasion of osteosarcoma cell. Mol Cell Biochem. 2013:373(1-2):201-10.

\section{Publisher's Note}

Springer Nature remains neutral with regard to jurisdictional claims in published maps and institutional affiliations. 